This is an Accepted Manuscript of an article published by Taylor \& Francis in Contemporary Music Review on 29/03/18, available online: https://www.tandfonline.com/doi/full/10.1080/07494467.2017.1452687 
Pre-proof manuscript for publication in Contemporary Music Review 36(6), 2017. Do not quote without author's permission.

\section{Drastic Allure: Timbre Between the Sublime and the Grain}

\section{Isabella van Elferen}

\section{Paradox}

Timbre is simultaneously one of the most powerfully immersive and one of the most ungraspable properties of music and musical aesthetics. The dreamy combination of harp and flute at the opening of Debussy's Prélude à l'Après-Midi d'un Faune, the eerie juxtaposition of electronic sounds and boy soprano in Stockhausen's Gesang der Jünglinge, the unworldly beauty of Maria Callas's performance of "Casta Diva" from Bellini's Norma: in all these cases it is timbre that immediately and physically transports us into dreaminess, eeriness, or unworldliness. And yet we know so little about the musical agent that has this power. What is timbre? How is it possible that its irresistible lure draws us mind and body into worlds of music?

The "Casta Diva" aria, which Callas performed many times, is a good example of the problems that timbre presents. Why does Maria Callas's version of that aria move me to tears every single time I hear it, even when her voice is as sublime as it is evidently less-thanperfect? Her pitch was not always precise, her passaggios unpleasantly audible, her phrasing unconvincing at times, and her wobble notorious: and yet Callas's voice never fails to take my heart, and that of thousands of other listeners, on a flight of magic. This sublime aesthetic experience is caused and accompanied by an almost prosaic degree of physicality. Callas's command of the "mask" - the resonant cavities of the face which aid vocal timbre -, the differance between the vowels " $a$ " and " $i$ " in this particular aria, the breath support sustaining her renowned legato and messa di voce: and all of these corporeal factors have immediate consequences in the shape of equally corporeal goose bumps and teary eyes. 
Pre-proof manuscript for publication in Contemporary Music Review 36(6), 2017. Do not quote without author's permission.

The fact of timbre seems powerful beyond comprehension. It is terrifying, overwhelming, noumenal. Like composers and music philosophers have done since the eighteenth century, I must resort to discourses of the sublime here, as there is no critical idiom in which to assess timbre - there are not even adequate words to describe it, nor is there a definition that is more precise than one ex negativo: timbre is, in official musicological terminology, "the difference between two tones with the same pitch and volume". Timbre, thus, is defined merely as something that is not something else, i.e. pitch or volume. But what is that something? The synonym "tone colour", which is used even by timbrally orientated composers such as Schoenberg and Boulez, is a rather powerless, synesthetic conflation, a visual metonymy used to describe an auditory phenomenon. When we describe specific timbral qualities, metonymy slides into adjectives, and loses even the last semblance of precision: the fact that timbres are hollow, or warm, or bronze, does not tell us very much at all beyond a subjective assessment. Failing even adjectives, the last resort of putting timbre into language is that of onomatopoeia: the "chirping" of birds, the "chiming" of a church bell, the curious sonorities of a "didgeridoo." Neither metonymies, adjectives, nor onomatopoeias clarify what timbre is or what it does: instead, along with descriptions of timbral aporia, they remove us ever further from the very Thing we are trying to capture within the boundaries of language.

If it is difficult to describe timbral sonority with any precision, its critical assessment is even more problematic. What musicological or philosophical frameworks are available to evaluate an aspect of musical aesthetics that cannot be sufficiently captured in words? Or to put it differently - what leverage does thought have in an area where language fails? We may study the phenomenon from a material perspective by investigating the circumstances of timbral production or through a Fourier analysis of the timbral spectrum, but this ultimately leads back to the same problem: how can we analyse the ways in which something as 
Pre-proof manuscript for publication in Contemporary Music Review 36(6), 2017. Do not quote without author's permission.

physical as Callas's vocal tract lead to the apparent dissolving of any physical relation in sublime aporia? How do we assess the replacement of the human being Sophia Cecelia Kalos by the unattainable diva Maria Callas and ultimately by "La Divina," the ephemeral deity whose sole worldly presence exists as the indescribable quality of a timbre? There seems to be an abyss separating timbral production from timbral aesthetics, one that music philosophy has not been able to bridge. Scholarly research on timbre focuses either on the former, material aspects or on the latter, less material aesthetics of this strange musical event, but never on both.

In an attempt to bridge the timbral abyss, this article analyses the binarism that pervades critical assessments of tone colour. In musicology, sound studies, and aesthetics alike, timbre is either considered in a materialist way as the manipulation of sound waves and instruments, or, in idealist fashion, as a sublime "communication of the incommunicable" (Nancy, 2007, p. 41). In his seminar on timbre, Pierre Boulez notes this binarist thinking, which he describes as the gap between the quantitative and the qualitative aspects of tone colour (Boulez, 1987, pp. 161-2). In what follows I argue that a theorisation of tone colour must start with the acknowledgement of the timbral paradox: timbre undeniably has material as well as immaterial components. Its paradoxical im/materiality engenders a sublime aesthetic experience that can be described as the aporia of being drawn into a void which appears to be real but which - the closer you get to it - flickers in and out of earshot and comprehension.

\section{The Timbral Sublime}

Definable only as sonorous difference, timbre has an intimate connection to musical identity. The difference between the sonorities of, say, oboe and clarinet leads to the timbrally defined identity of either instrument: because of its different materiality, an oboe does not sound like 
Pre-proof manuscript for publication in Contemporary Music Review 36(6), 2017. Do not quote without author's permission.

a clarinet, and that timbral difference identifies it as an oboe. Such musical identities, which point causally to physical origin, although based on negation alone, are often used as signifiers for extra-musical identities: the oboe timbre, for instance, is often used to identify pastoral moods, spheres, or characters. Attention to this form of timbral identity, whether conceived as causal or as inscribed, pervaded compositional practices at least as early as the Baroque, when specific roles were attributed to various instruments and voice types in dramatic works such as cantatas, oratorios, and passions (Steiger, 2002, pp. 119-125). Timbral identity-through-difference has pervaded Western music history ever since the Baroque, from Haydn's symphonies (Dolan, 2013, pp. 136-179) to the genres of popular music (Walser, 1993, pp. 41-44) and the multimedial practices of film and videogame composing, in which instrumental timbres anchor visual narratives in sonic signification. But timbre cannot be equated with identity and signification: distorted guitar sounds may be typical of metal, they are not in and of themselves identical with it, and sweeping string timbres may often be used in romantic comedies but do not in and of themselves signify Hollywood romance. Timbre importantly eludes and exceeds such precise identifications and significations, and that is because of the negative dialectic at the heart of its phenomenology. Timbre, after all, can only be defined through what it is not.

Diverging from the practice of using timbral difference to represent extra-musical identities, the early Romantic era favoured the idea that sonorous difference afforded, rather and more in line with timbre's evasive phenomenological structure - a negation of precise identity or signification. Composers and music philosophers like Johann Gottfried Herder and E.T.A. Hoffmann urged composers to abandon words and concrete meanings, and to express in their music those Things that words can never say: the undefined, the unknown, the infinite. Herder describes the effect that specific timbres may have on the sensitivity (“Empfindbarkeit”) of each listener (Herder, 1878, pp. 98-99). As different timbres may lead 
Pre-proof manuscript for publication in Contemporary Music Review 36(6), 2017. Do not quote without author's permission.

to different sensitive experiences (102), pinning down timbral meaning and affect would mean to pin down the "labyrinth" of the human soul (105), and that would equal the end of "tone pleasure" (113). Trying to describe the timbral experiences permeating this labyrinth, Herder contends, must remain impossible, as words cannot possibly express the depths of timbral power on the sensitive soul (162-163). If this sensuous, undefinable tone-pleasure, that is, the aesthetic meeting with timbre (cf. Dolan, 2013, pp. 71-87), is the indescribable essence of all music for Herder, E.T.A. Hoffmann takes this thought further into the realm of sublime aporia:

Instrumental music is the most romantic of all arts, for its sole subject is the infinite. [M] usic discloses to man an unknown realm, a world that has nothing in common with the external sensual world that surrounds him.... (Hoffmann, 1813, p. 35)

Instrumental music, because it surpasses language, was also considered to be able to surpass the mundane world: created in such free and imaginative forms as Lieder ohne Worte (Felix Mendelssohn Bartholdy, 1832-1845) it was a popular vehicle to 'bear the listener's soul in rapid flight into the faraway spirit realm of sound' (Hoffmann, 1813, p. 41). Romantic instrumental music, which Richard Wagner later called 'absolute music,' revolved for a large part around the expressive potential of pure timbral sonority: listeners were captured, raptured, by instrumental differences forming musical entities existing only in the ephemeral bowings of a violin or the passing flurry of woodwind (cf. Hamilton, 2007, pp. 84, 74-78). The open-endedness of this aesthetic invited all sorts of sublime terrors and delights: 'Beethoven's instrumental music', Hoffmann writes, 'opens up to us the realm of the monstrous and the immeasurable' (Hoffmann, 1813, p. 41). This focus on the sublime 
Pre-proof manuscript for publication in Contemporary Music Review 36(6), 2017. Do not quote without author's permission.

experience of instrumental timbre, Carl Dahlhaus argues, led to an elated, often metaphysical or mystical discourse around instrumental music (Dahlhaus, 1989, pp. 88-96, p. 243).

The early Romantic age of the eighteenth century, of course, was aesthetically sensitive precisely to timbre's sublime ephemerality. Because timbre possesses an aesthetic power extending far beyond its physical origins, it became the most extolled of all musical qualities in the Romantic era: tone colour was considered to be a noumenon, the musical passage into the realm of infinite terror and overwhelming aporia (cf. Goehr, 2007, pp. 148175). It epitomised Burke's sublime and Kant's noumenon: timbre was a musical Thing initself beyond comprehension, and as such, according to Herder, it was "the essence of music" (“das Wesen der Tonkunst," Herder, 1878, p. 101). Because timbre expresses "the infinite” (Hoffmann), it is a musical form of sublime in Kiene Brillenburgh-Wurth's definition: because of music's eternal deferral of referentiality and meaning, the musical sublime sets the listener in a sublime oscillation that remains without resolution (Brillenburgh-Wurth, 2009, pp. 8-9).

Later Romantic composers did describe timbral expression in slightly more detail. In his Grand Traité d'Instrumentation et d'Orchestration Modernes (1844), Hector Berlioz set out to define the expressive possibilities of specific instruments in an extensive treatise on instrumentation and orchestration. His purpose was

to show the range and certain essential details of the mechanism of each instrument, and then to examine the nature of the tone, particular character and expressive potential of each - a branch of study hitherto greatly neglected - and finally to consider the best ways of grouping them effectively (Berlioz, 1844, p. 6). 
Pre-proof manuscript for publication in Contemporary Music Review 36(6), 2017. Do not quote without author's permission.

Differently than in the Baroque, where oboes d'amore were often used to signify love, and bass structures often represented the divine order, Romantic timbres were not tied to specific signifieds. Rather, they expressed feelings, shades, and subtleties that could only be described in words - if at all - by way of vague adjectives. Instrumental timbres now represented orchestrally embedded individuality, like in the idée fixe of Berlioz's own Symfonie Fantastique (1830), which wanders between various instrument groups and movements. The permutations of the idée are differentiated through rhythm and harmony, but most importantly through timbre, the individual differences of the various instruments. We can speculate, based on Berlioz's treatise and writings, what these timbral individualities may mean. But only the idée is fixed - not its identity; not its meaning, which must remain as vague as the composer's passion, or the Thing that is Harriet-in-herself: an ideal, a noumenon. In Gustav Mahler's music this emancipation of instrumental timbre, and with it the wordless, imprecise, aporetic expressive capacity of tone colour, reached an unequalled degree of precision. Consider the 'fate' motif in the first movement of his Sixth Symphony (written in 1903, re-orchestrated by the composer before and after the first performance in 1906), in which A major in the trumpets changes to A minor in the oboes. The fact that it is difficult to imagine this harmonic motion the other way around, with major in the oboes leading to minor in the trumpets, indicates how timbral identity - and in this case there clearly is one - is simultaneously extremely hard to define and deeply culturally engrained. The fate naming the motif is the unnameable fate of timbre. These and similar practices led to what Dahlhaus calls 'the emancipation of timbre' in nineteenth-century music, which gave it 'an aesthetic raison d'être and significance of its own' (Dahlhaus, 1989, p. 243).

Timbre urges epistemological questions. What exactly can we know about Romantic - and early Modernist - timbral identities? Berlioz appears to be quite precise in his ascription of expression and identity to instrumental timbres. He considers the violin to be the 
Pre-proof manuscript for publication in Contemporary Music Review 36(6), 2017. Do not quote without author's permission.

most expressive and nuanced instrument available to a composer, and enumerates the various moods that can be expressed by playing specific keys on a violin. D major, for instance, is 'gay, noisy, rather vulgar', while the major key just a semitone higher, E flat, is 'majestic, quite sonorous, gentle, grave' (Berlioz, 1844, p. 32). But while Berlioz's characterisations seem to describe precise musical identities, the 'majestic' nature of E flat major in a violin timbre, rather than drawing the theorist closer to the mechanics of timbral phenomenology or even epistemology, brings her back to the idealist realm of timbral metaphor.

Even when noumenal, thus, Romantic timbre was always seen as a form of musical difference and musical identity (however ephemeral), and in that sense a form of musical signification (however imprecise): the difference between violin and viola timbres marks different materialities, and therefore identities and signifieds. Even if those identities and signifieds are not as clean as they would have been in linguistic signification, the physical difference that evokes them is tangibly present in every timbral event. The Russian instruments in Glinka's operas (cf. Dahlhaus, 1989, p. 220), for instance, signify a pleasantly hazy but physically identifiable colour locale through tone colour. In a similar way, timbre is an indefinable sonic marker of genre identity. Bel canto is, again, an eminent example. This genre revolves around the celebration of sublime vocal timbres: but which timbres exactly, how do we describe them, and why do we think them so divine if they emanate from physical bodies?

The Romantic aesthetics of tone colour exceeds the material, but Romantic idealism, with all its sublime desire, is unable to obliterate timbre's corporeality. The musical sublime engendered by tone colour cannot merely be described as an 'empty sign' in BrillenburghWurth's terms $(2009$, p. 2). Timbre is a firmly materially rooted, but veiled sonic sign whose signified lies somewhat beyond the clear grasp of logocentrism, and therefore gets inscribed 
Pre-proof manuscript for publication in Contemporary Music Review 36(6), 2017. Do not quote without author's permission.

as numinous (cf. Dolar, 2006, p. 19). Matter and idea, object and Thing converge in timbre's paradoxical material sublime.

\section{The Timbral Imperative}

The ephemeral power of timbre as celebrated in Romantic music was developed into an aesthetics of timbre by four key twentieth-century composers: Arnold Schoenberg, Pierre Schaeffer, Karlheinz Stockhausen, and Pierre Boulez.

Timbral difference was first theorized in its own right - that is, separate from orchestration - in the early twentieth century by Arnold Schoenberg, who dedicated a large part of his Harmonielehre (1911) and of his composing to timbre. Schoenberg was a great admirer of Claude Debussy, whose compositions he considered to be examples of the mysterious power of tone colour. The timbral impressionism of Debussy's Prélude à l'AprèsMidi d'un Faune, for instance, resonates in Schoenberg's 'Farben', No. 3 from his Fünf Orchesterstücke from 1909. The subtitle of the piece is 'Summer Morning by a Lake: Chord Colours,' which reflects the development of his compositional and theoretical focus on tone colour during the late 1910s.

In his Harmonielehre Schoenberg insists that timbre, which he consistently refers to as colour (Farbe), is the most important component of a tone, and that pitch is just one of its dimensions: after all, what is pitch but the collection of wave frequencies and harmonics generated by a specific timbre (Schoenberg, 1911, p. 506)? For this reason, some of the chords he writes seem to look like dissonant clusters but are in reality a close conglomeration of harmonics. As an example he describes the following chord group from his monodrama Erwartung: by letting different instruments play each layer of the harmonic complex, Schoenberg illustrates that each tone consists of infinitely many tones, each of which can have their own sonic identity (Schoenberg, 1911, p. 502). 
Pre-proof manuscript for publication in Contemporary Music Review 36(6), 2017. Do not quote without author's permission.

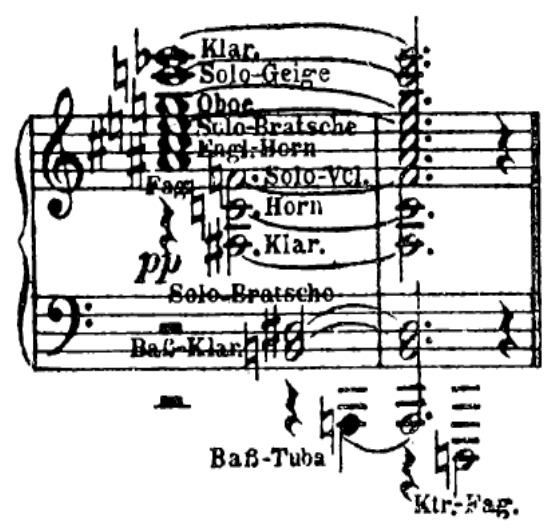

Insisting that tone colour is capable of expressing the inexpressible, Schoenberg ends his treatise on harmony with a passionate plea in which he famously dreams up the notion of 'Klangfarbenmelodie', tone colour melody.

[This] has the appearance of a futuristic fantasy [which] I firmly believe is capable of heightening in an unprecedented manner the sensory, intellectual, and spiritual pleasures offered by art. I firmly believe that it will bring us closer to the illusory stuff of our dreams; that it will expand our relationships to that which seems to us inanimate today, as we give life from our life to that which is temporarily dead for us, but dead only by virtue of the slight connection we have with it.

Tone-colour melodies! How acute the senses that would be able to perceive them! How high the development of the spirit that could find pleasure in such subtle things! (Schoenberg, 1911, p. 507, transl. IvE)

Letting impressionist and expressionist compositional efforts converge in the ineffable musical quality of timbre, and explicitly referring to tone colour melody as the music of the 
Pre-proof manuscript for publication in Contemporary Music Review 36(6), 2017. Do not quote without author's permission.

future, Schoenberg's treatise culminates here in what could be considered a timbral imperative, the urgently and teleologically formulated call on composers to focus on timbre as the highest and most ineffable form of musical expression. He describes tone colour as sensory, intellectual, and spiritual: instead, he hopes that timbre's ineffability will evoke illusions, dreams, and a new kind of vitality. This description is clearly coloured by the timbral idealism that had marked instrumental composing since the late eighteenth century.

Schoenberg's timbral imperative was followed by his pupils, among them Alban Berg and Anton Webern. An example is Webern's orchestration of Bach's Ricercar from the Musikalischen Opfer (1935), in which the original organ melody moves through trombone, horn, harp, flute, and violin. Here the exploration of timbral identity and difference is the sole theme of musical composition and expression. It is important to realise that, despite Webern's seemingly rational (serialist) compositional starting point, this treatment of timbre is thoroughly Romantic in its conception: Webern explores Schoenberg's expressionist notion that tone colour is a form of absolute music which can express the inexpressible stuff of our dreams - very similar in spirit to an account of instrumental music by the early Romantic writer Jean Paul: 'Each note seemed a celestial echo of his dream, answering to beings whom one did not see and did not hear...' (Paul, 1795, p. 27).

The generation after the Viennese serialists focused on the creation of new electronic timbres. The most influential composer and theorist in this field is undoubtedly Karlheinz Stockhausen.

Extending Schoenberg's timbral imperative, Stockhausen emphasised that the composer of electronic music should strive to create new timbres that are free from any previous connotation. Associations, he maintained, distract the listener's attention from 'the autonomy of each sound world' (Stockhausen, 1958, p. 374), and therefore he believed that electronic music has its own phenomenology of sound. His 1955-6 composition Gesang der 
Pre-proof manuscript for publication in Contemporary Music Review 36(6), 2017. Do not quote without author's permission.

Jünglinge combines technological and human sounds. The work is composed for five groups of speakers which should be placed around the listener, and consists of the musical dialogue between a recording of a boy soprano singing the words 'Preiset den Herren', electronically generated sine tones, and electronic clicks. Stockhausen's own description of the work illustrates his timbral ideology: 'In "Song of the Youths" a unity of electronic - synthetic and sung - natural - sounds has been achieved: an organic unity, which seemed to be a far utopia even three years ago"” (Stockhausen, 1964, p. 49f, transl. IvE). Stockhausen's electronic experiments, thus, brought into practice a timbral imperative that was not just marked by the idealism of an autonomous timbral Thing - he complained as late as 1973 that Schoenberg's dream of tone colour melody had still not been brought into practice (Stockhausen, 1973, p. 361) - but simultaneously also by the materialism of timbral embodiment and experimentation.

In a less ideological but similarly idealist manner, Boulez describes the development from baroque instrumental signification, through Berlioz's orchestration treatise and Schoenberg's Klangfarben, as a liberating movement away from the constraints of fixed instrumental identities which impeded timbre's potential for infinite and diffuse expression. He urges composers to explore the expressive capacities of this uncharted territory of musical communication. His idealist reading of timbral ontology verges on Romantic notions of the musical sublime. He discusses both components of this n(o)umous sublime: the Kantian inapproachability of the timbral noumenon on the one hand, and the numinous veiledness of timbral referentiality on the other:

Timbre does not function on its own, but the acoustic illusion of timbre is brought out by the way the music is composed. From this I deduce two notions of timbre used in instrumental timbre: raw timbre and organized timbre. In the first case composition 
Pre-proof manuscript for publication in Contemporary Music Review 36(6), 2017. Do not quote without author's permission.

acts from the outside. In the second case it works from the inside of the sound-object. The reality and identity of the instrument can thus be enveloped in a network of ambiguities which either hides it within a fused sound-object or reveals it in its absolute state. (Boulez, 1987, p. 169)

To me the functional possibilities of timbre only seem valid if they are linked to language and to the articulation of a discourse through structural relationships; timbre both explains and masks at the same time. (Boulez, 1987, p. 170)

Even though it is informed by material practices of composing 'raw' timbre - from the replacement of the recorder by the flute to the use of tape recorders and sound wave manipulation - Boulez's assessment of 'organised' timbre tends towards a numinous, 'absolute' ineffable. When he then tries to liken timbre to language, in order to maintain his ambivalent assessment, he contends that it 'explains and masks at the same time': timbre both identifies its physical source and does something entirely different, something indescribable that is "a signpost for the emotions" (Boulez, 1987, p. 170).

The evocative, sometimes almost metaphysical assessments of timbre's expressive potential by these three timbrally orientated twentieth century composers, in fact, reflect a renegotiation of the Kantian sublime, if perhaps a slightly more materially constituted sublime: Schoenberg's, Stockhausen's, and Boulez's ideas about timbre all foreground the persisting idealist distance between timbral object and timbral Thing in-itself. Equally persistent throughout their writing, however, is the strange co-presence of both in the paradoxical timbral event.

\section{Materiality and Disenchantment}


Pre-proof manuscript for publication in Contemporary Music Review 36(6), 2017. Do not quote without author's permission.

The extracts in the previous two paragraphs illustrate that modernity's intense attention for timbre as sublime or noumenal has always been accompanied by an acute awareness that the allegedly unspeakable expressive power of timbre had a clear material component. Berlioz's treatise on instruments, for instance, contains extensive sections on how not to play your instrument or how not to treat your orchestra - he complains about the fashion of open-air performances which can only go wrong for countless reasons; and most trumpeters should simply not even try to play trills, as this is physically impracticable (e.g. Berlioz, 1844, p.188, p. 204). As timbre represents both the sonic result of a material cause and the sonic identifier of an ungraspable noumenon, moreover, its material components have been treated in surprisingly contradictory ways. On the one hand organology and instrumental or vocal pedagogy are often quite descriptive, and do not deal with the more intellectually or imaginatively challenging sides of their subject matter. On the other hand, the focus on noumenal identity has led to the fetishisation of material objects such as historical instruments in 'authentic' performance practice, the hysterical prices paid for Stradivarius violins, the fandom around Fender Stratocaster guitars.

Focusing on the material aspects of timbre, Roland Barthes has intervened in the idealist discourse around timbre by theorising vocal timbre as 'the grain of the voice' which signifies "the body in the voice as it sings, the hand as it writes, the limb as it performs" (Barthes, 1977, p. 188). There is a comforting amount of common sense in Barthes' material definition. Of course there is a materiality about vocal timbre: we can hear cigarettes on some singers' voices, we know it is hard to play trills on trumpets, and that Stockhausen's sinus tones were meticulously crafted in the WDR studios. Timbre, after all, may affect an immaterial differance in attributed meaning, but starts with a difference in physical origin.

This physical origin, moreover, can be scientifically measured in a number of unambivalent ways. Timbre is defined by the timbral envelope: the attack, decay, sustain, and 
Pre-proof manuscript for publication in Contemporary Music Review 36(6), 2017. Do not quote without author's permission.

release of a given sound together comprise the individual timbre of that sound (Tagg, 2013, pp. 277-279). Within this model, the pitch of a sound is determined by the shape, frequency, and harmonics of the sound waves. The frequency spectrum of a sound - that is the number of overtones it has and the moments at which these are audible in the timbral envelope - is a major factor in the timbre of that sound (Tagg, 2013, pp. 279-280). The channels that generate the sound, for instance the shape of the singer's larynx and throat in the case of vocal timbre, determine which overtones will be generated: for this reason, even octaves can appear to be out of tune when sung by different voices. We can also analyse the actual sound waves themselves: sine waves produce a different timbre than square, triangle, or sawtooth waves. Another aspect of timbre is acoustic setting. In live situations, the resonance and reverb provided by a sound's location may make overtones either more or less audible, and therefore influence timbre (cf. Blesser and Salter, 2007, pp. 16-66). So Barthes is right: timbre signifies the body as it sings, as it is the simple result of attack, sustain, decay and release of sound waves; of the overtones brought into sound by physical formants like wood, stone, or larynxes; of live or recorded acoustics.

The developments in the field of music technology have, since the 1950s, led to a further focus on timbre as well as an intensification of attention for its material aspects. With technology we can not only manipulate timbre but also even create new, previously unheard timbres: Stockhausen's experiments stretched the boundaries of electro-acoustic timbre, and the work of composers such as Pierre Boulez and Gérard Grisey at IRCAM in Paris explored, alongside other techniques, the extent to which the full harmonic spectrum of timbre can be employed in composition (cf. Anderson, 2000). After Schoenberg's tone colour melody, with its clear idealist genesis, spectral music in all its forms was arguably the first purely materialist form of music with timbre as its key parameter. 
Pre-proof manuscript for publication in Contemporary Music Review 36(6), 2017. Do not quote without author's permission.

As the rise of timbral materialism was accompanied by the democratisation of compositional agency, the creation of new sounds is by no means restricted to research institutes and professional studios. In the early 1960s Bob Moog had invented an affordable means to create new sounds with the help of a keyboard interface, which meant that timbral experiments became both easier and cheaper. Since the digitisation of sound in the 1990s and the subsequent rise of file- and software sharing via the Internet, this ease of access and of use increased even more: music software such as Ableton Live, Logic, Pro Tools, and FL Studio is available to many people, and a simple Macbook or PC can provide a studio for domestic musical creation. An interesting, relatively recent example of do-it-yourself timbre is provided by Low Frequency Oscillator (LFO) software and plug-ins, which allow users to change the wave forms of the sounds they want to use, and to filter out and modulate frequencies. LFO software controls the length and shape of audio waves, so that effects like vibrato, tremolo, crescendo, glissando and distortion can be programmed into the timbre of a tone. LFO software answers to Stockhausen's timbral imperative and takes it forward in manners that he could not have foreseen: it enables home users to create wholly new, autonomous sound worlds which are then globally distributed via the Internet and further refined by swarms of networked, do-it-yourself timbral materialists. Despite the evident materiality of the timbre produced by LFO software, though, it is important to be aware of the immediate simultaneity of this timbral materiality with its immaterial counterpart. The timbre produced with this software is the sole sonic identifier of the dubstep genre, in which deep sub-basses are given their characteristic LFO "wobble." Effects like vibrato, tremolo, crescendo, glissando and distortion are employed to generate syncopated rhythms, which creates the unusual sound of timbre-led rhythmical patterns. LFO wobbles and timbral rhythms are assessed by fans as alive and alien, dirty and heavy, or simply as 'the wub' and 
Pre-proof manuscript for publication in Contemporary Music Review 36(6), 2017. Do not quote without author's permission.

'wab wab wab' - and so timbral materialism reverts, once again, to idealism, adjective, and onomatopoeia.

The ephemeral lure of the wub (and of other science fictional applications of music technology) notwithstanding, all these technological developments arguably lead to a disenchantment of sorts: even though the immaterial aspects of timbre are powerful and immersive, its materiality is a wake-up call for all-too Romantic notions about absolute music. Timbre is not magic. It's the result of hard work: physical, technological, and auditory labour on the shaping of sound waves and harmonics and formants. This is true for biologically generated timbre also. Any singer will recognise the fact that trying to create an acceptable timbre for 'Casta Diva' is devastatingly difficult. It involves intense strain on the diaphragm, core muscles, and legs for those excruciating sustained notes; it involves the positioning of tongue and lips to create vowels that carry rather than muffle timbre; it involves connecting all possible head and chest resonance to sustain the melodic arch of the aria by way of a consistent colouring; it involves the utmost mental and physical concentration in maintaining the legato without which this aria inevitably dies... and when the singer finally has all her physical generators of timbre in place, only then can she start thinking of how she is going to achieve the unspeakable vulnerability that the libretto wants her to express - but all this while her corporeal framework is set for hurricane strength. Timbre, from this perspective, has nothing at all to do with the sublime: it is painstaking physical labour, the aching 'limb as it performs' (Barthes, 1977, p. 188).

Although Barthes' essay was not followed by many publications on timbral physicality, both musicology and critical theory have since adopted embodiment and materiality in their respective methodologies. The so-called 'material turn' in the humanities focuses on the corporeal production, perception, and appropriation of cultural and sonic events. In their provocatively titled article 'Down with Disembodiment; or Musicology and 
Pre-proof manuscript for publication in Contemporary Music Review 36(6), 2017. Do not quote without author's permission.

the Material Turn,' Holly Watkins and Melina Esse propose that a material turn would only be beneficial to musicology if the materiality of the musicking body would be considered as 'rooted in the organic and routed through the cultural' (Watkins and Esse, 2015, p. 162).

Despite this inclusive premise, Watkins' and Esse's is a carnal phenomenology that does not take into account the less material aspects of the musicking voice, the case study they discuss. Instead, theirs and other materialist studies of the voice and its corporeal roots all but obliterate the question of timbre. If and when timbre is included in carnal phenomenologies, it is studied exclusively in its physical causality. Nina Eidsheim's book Sensing Sound (2015) focuses on the corporeal performativity of singing, and listening to singing. Through this lens she explores a wide range of vocal musical practices such as contemporary sonic art and classical singing pedagogy, which she states imposes a specific timbral ideal as an 'aesthetic straightjacket' (Eidsheim, 2015, p. 140ff). Eidsheim explicitly rejects any form of musical immateriality, polemically referring to immaterial approaches to music as 'metaphysical' (Eidsheim, 2015, p. 15). As it employs such exclusive methodologies, thus, the 'quest for voice' (Goehr, 1998) has garnered important insights about the political performativities of voices, but has also led to a reduction of vocal timbre to its material aspects in which voice becomes a symbol for corporeality and corporeal agency.

Instrumental or electro-acoustic timbres, moreover, are only rarely included in material studies of music, in spite of their evident materiality and rootedness in tangible practices. It would seem that the material turn has focused on certain embodied aspects of musicking at the cost of its non-corporeal and non-physical components, and this is just as great a loss to the study of timbre as is the over-emphasis on its immaterial aspects. From the compositions and writings discussed in the first part of this article, however, it is clear that both aspects are needed for the analysis of timbre. Material musicology's attention to the corporeal circumstances of the grain's production only presents half a timbral theory. The 
Pre-proof manuscript for publication in Contemporary Music Review 36(6), 2017. Do not quote without author's permission.

concept of timbre ensuing from these corporeal analyses is unmusical in that it does not consider the more ephemeral aspects of timbral aesthetics. Just as timbre is not limited to the disembodied ephemerality advocated in idealism, so it is not limited to the singing body alone.

In a sense, I would argue, an exclusive focus on timbral materiality simultaneously obliterates the transcendental idealism that dominated timbral theory since the Enlightenment, and instrumentalises - but maintains - that same idealism. As they choose not to discuss any less material aspects of musicking, carnal phenomenologies, in fact, confirm the dichotomy. Perhaps that is why they only very seldom discuss timbre, a phenomenon that has two simultaneous sides. The one material theorist that does analyse timbre, Roland Barthes, similarly keeps timbral dualism in place: even though he seems to release timbre from idealism by way of body, language, and identity, he emphatically retains the idealist notion that there is a certain timbral hors-texte, that which he claims - replacing noumenous terminology with psychoanalytic symbolic - is the 'loss' and 'jouissance' of the musicking voice's ungraspable grain (Barthes, 1977, p. 179, p. 183; cf. Dolar, 2006, pp. 71-74). We observed this same idealist binarism in Boulez's discussion of timbre's veiled language, and it is echoed, too, in Nancy's 'communication of the incommunicable' quoted above: time after time, timbre is considered as corporeal and compared to a materially informed language, and yet time after time the comparison yields the same idealist result - that of sublime aporia.

If timbral idealism, thus, appears to exclude the evidently physical elements creating tone colour, timbral materialism lacks the immaterial components that are inherent to tone colour aesthetics. The timbral binarism noted at the beginning of this article is persistent. Timbre in-itself versus timbral object: though both are inextricable parts of the timbral event, in the currently prevailing, mutually exclusive theories of timbre the twain shall never meet. 
Pre-proof manuscript for publication in Contemporary Music Review 36(6), 2017. Do not quote without author's permission.

\section{Immaterialist Materialism}

Timbre is intrinsic to sound and vital in music. Timbre is what makes bodies ache, notes sing, and listeners soar. Timbre is a sonic cause, an ineffable idea, and with that an intellectual enigma. It raises impossible but lingering questions. The problem outlined at the opening of this article has has not been solved. How can something be simultaneously ineffable, metaphysical, transcendent, and physical, corporeal, material? Both sides of the binary have been extensively explored in composition, musicology, and philosophy, but two separate sides they remain. And as long as these two sides are separate, timbre is not understood.

It would seem to me that the only way to address timbre with critical precision is to accept its paradoxes. A comprehensive theory of timbre requires an engagement with both sides of the timbral binary, but to achieve such a bridge across the timbral abyss a precarious philosophical hurdle must be taken. Timbral theorisation necessitates a musical exploration of the area between materialism and idealism which would allow for fluidity and movement between numinous ineffability and firm materiality. Such an immaterialist materialism can be afforded by a combination of Jean-François Lyotard's, Vladimir Jankélévitch's, and Carolyn Abbate's ideas regarding musical experience. All three theorists describe in some way the convergence of materialism and idealism in music, and all three locate the problem of musical non/signification precisely within that convergence. Only one of them - the nonmusicologist, surprisingly - writes about timbre, but it is entirely possible to construct a theory of timbre through their combined perspectives.

In his essays on music Lyotard often veers towards the sublime, and in his essays on the sublime he keeps coming back to the problem of music. The connection between the two in his thinking lies in the aporia caused by music's non/signification: as a poststructuralist he is interested in the ways in which music appears to escape straightforward signification. Like 
Pre-proof manuscript for publication in Contemporary Music Review 36(6), 2017. Do not quote without author's permission.

Barthes, Lyotard considers this musical evasiveness a result of the convergence of the physical and the non-physical in music. And like Barthes, he regards timbre as the nexus of both paradoxes in music. But differently than in Barthes' reduction, Lyotard does not distort this paradox to either the materialism of corporeality or the non-sequitur of idealist inapproachability. Instead, over the course of his many writings on music he keeps tracing and theorising the simultaneity of both in the strange event of tone colour.

Lyotard's discussions of timbral signification and identity are led by the same reasoning as Boulez's writing on the same topic: he describes how twentieth-century music has emancipated timbre from the fixed signification imposed on it by music history, and contends that twentieth-century music has finally achieved a timbre that lacks any signified (Lyotard, 1991, pp. 172-173; Lyotard, 1996, p. 40). More explicitly than Boulez, however, Lyotard analyses the ways in which listeners are physically, mindlessly, meaninglessly touched by sound, and specifically by timbre. He coins the phrase 'sound-feeling' (sentiment sonore) to describe the singularity of music's touch (Lyotard, 1991, p. 176): 'The enigma of this touch [of art, and music in specific] is that it affects thought at the same time as the body' (Lyotard, 1996, p. 41). The fact that the sentiment sonore keeps returning in one shape or other throughout Lyotard's work indicates just how important and puzzling this sound-feeling was to him. It does develop over the course of his writing. In his earlier essays, he advocates an explicitly sublime idealism of timbre: in 'After the Sublime' he relates this touch to 'the Thing', which is extimate to the mind and to questioning (Lyotard, 1991, p. 142). In his later work, while never really leaving the philosophical area of the sublime, Lyotard moves toward a physically induced aporia of not-knowing rather than the classical sublime of nonsignification. In 'Music and Postmodernity' (1996) he writes that 
Pre-proof manuscript for publication in Contemporary Music Review 36(6), 2017. Do not quote without author's permission.

[i]n striving for the ideal of causing the ear to sense sound-matter - timbre - freed from all destination, contemporary music pushes to the extreme its 'stake' in the aporia constitutive of all music: to make heard that which escapes in itself all hearing, to address what is not addressed. (Lyotard, 1996, p. 43)

It is clear that this version of Lyotard's timbral sublime moves toward what later became known as affect theory (cf. Leipert, 2013). While affect theory, however, is an explicitly materialist, corporeally orientated branch of cultural studies, Lyotard maintains a careful balance between the material and the less material in music and timbre. As music touches body and mind at the same time and with the same intensity, he introduces the concept of anima or body/thought, a 'substance soul with the faculty of being affected,' and which indeed only exists as affected (Lyotard, 1997, p. 242). One of the key factors that engender this substance-soul, and that produce a sentiment sonore, is the sublimely paradoxical force of timbre (Lyotard, 1997, pp. 242-3).

Lyotard's timbral sublime cannot be framed through the binary structure of idealism. It could not have had timbre - which does not let itself be theorised in binary structures - as its main manifestation if it was conceived in this dichotomous way. Instead, Lyotard's sublime is a possible affordance of musical interaction: this specific affordance is simultaneously located, throughout his work, in the ineffable aporia of the timbral Thing (Lyotard, 1991, p. 142), and in the palpable, often mundane, and at times painful physicality of the sentiment sonore (Lyotard, 1991, p. 176). The sublime occurs in the singularity of the aesthetic moment, which always affects both corporeal and mental responses. Lyotard theorises the aesthetic moment as the halting of thought in the midst of an event, as it occurs and halts time within its own eventness: the event is 'infinitely simple,' and because of this it can only be approached through a privation of thinking. The famous 'arrive-t-il' represents 
Pre-proof manuscript for publication in Contemporary Music Review 36(6), 2017. Do not quote without author's permission.

the disarmament of thought in the occurrence of the event: we simply ask 'is it happening, is this it, is it possible?' (Lyotard, 1991, p. 90, italics in original). In this suspension, this nothought, there is only the intensity of the moment, which does not warrant any prediction or premonition. Anything may happen next, or nothing may happen. The surrender to the eventness of the event, as we await the unknown, may arouse anxiety or pleasure, and herein lies its affinity - but not its equation - with classical sublime aporia. Lyotard theorises this un-thinking occurrence as an 'intensification of being' that eliminates the possibility not just of thought but of any context: "The mark of the question is "now", now like the feeling that nothing might happen: the nothingness now' (Lyotard, 1991, p.: 92).

Even though Lyotard's is the only theory of timbre that is based on the timbral fact of immaterialist materiality, his assessment of it remains haunted by his own poststructuralist focus on signification. Just like Barthes does, Lyotard keeps framing his thinking in terms of a dichotomy between signification and non-signification, or an excess of signification (theorised by Mladen Dolar as the psychoanalytical objet petit a; Dolar, 2006, p. 73-4). But the paradoxical event of timbre demands inclusion rather than exclusion: it must be thought of not only as material and immaterial, but also as signification and non-signification. Timbral theory requires a move beyond the dialectic of text and hors-texte.

Jankélévitch's book Music and the Ineffable appears to perform this move. Jankélévitch does not just acknowledge the paradoxical aporia between mind and matter induced by music: he wallows in what he describes as 'a fruitful perplexity that is more ineffable than untellable' (Jankélévitch, 2003, p. 96). Perhaps it is because the book was written before poststructuralism existed, and perhaps also because the author was a musician (Jankélévitch played piano with Roland Barthes); but Jankélévitch is not as worried about music's lack of meaning as Lyotard is. Indeed, he says, the notion that there could be expression in music imposes not only logos but also utilitarianism upon meaningless sounds 
Pre-proof manuscript for publication in Contemporary Music Review 36(6), 2017. Do not quote without author's permission.

which in themselves can only express musicality (Jankélévitch, 2003, p. 15, p. 25, p. 37): 'In music, there is nothing to think about, and infinite thoughts - and this is the same - infinite speculation' (Jankélévitch, 2003, p. 83). His version of the ineffable, thus, attempts to overcome the binarism of musical signification/non-signification through inclusivity, which is a necessary component of a timbral theory based on immaterialist materialism. In his revelling in musical meaninglessness, however, Jankélévitch book increasingly privileges an immaterial understanding of music, to such an extent that the latter half of the book tends towards noumenal and even metaphysical interpretations of musical immersion (Jankélévitch, 2003, p. 110, p. 127).

In terms of materiality/immateriality binarism, Jankélévitch focuses on the ways in which music is almost able to eradicate subjectivity: in what is almost a premonition of Lyotard's arrive-t-il, he describes how the musician or listener is 'robbed of a self, nothing more than a vibrating string, a sounding pipe' (Jankélévitch, 2003, p. 1). Diametrically opposed to carnal phenomenologies of music, this assessment seems to come very close to the Romantic, idealist assessment of the musical sublime discussed in the first part of this article. But, like in Lyotard's sublime, Jankélévitch's version is physical as well, in that the listener becomes the string or the pipe: it operates implicitly from the starting point of immaterialist materialism (Jankélévitch's Romantically inclined poetic language is misleading at times). His understanding of music's immaterial materiality is in fact closely related to Lyotard's anima: 'Physical sonority is already something mental, an immediately spiritual phenomenon' (Jankélévitch, 2003, p. 76).

In Jankélévitch's ineffable assessment of music, the subject-dissolving 'bewitchment by a sonorous phantasm' (Jankélévitch, 2003, p. 2) is aided by the temporal dislocation it causes: the sonata creates its own time, whose chronological disobedience exceeds even the durée of Jankélévitch's teacher Bergson: the sonata is 'an enchanted chronology, a melodious 
Pre-proof manuscript for publication in Contemporary Music Review 36(6), 2017. Do not quote without author's permission.

form of becoming, time itself.' (Jankélévitch, 2003, p. 70; cf. p. 51, p. 96, p. 120ff). Here, again, there is an almost uncanny resemblance between Jankélévitch and Lyotard, who states that the sentiment sonore is "perhaps the most elementary presence of time or to time, the "poorest" degree or state (although it is not a state) of being-time: Durchlaufen"” (Lyotard, 1991, p. 176). This Lyotard calls a 'being-now' that is opposed to the being-there of Dasein and that is entirely subjected to the durée of music (ibid.). For Lyotard, the sensible aspect of musical experience is crucial in this, as it creates an 'arche-épochè of sensation' (Lyotard, 1997, p. 249). As usual, timbre is the operative factor for Lyotard - 'Timbre introduces a sort of infinity’ (Lyotard, 1991, p. 140) - but Jankélévitch does not specify any musical parameters of time, since music, rather, annihilates temporality: the mark of the question is now.

\section{Drastic Allure}

An immaterialist materialism of timbre foregrounds not just how entwined both aspects of tone colour are, but moreover also how important it is to recognise the evental nature - the arrive-t-il - of timbre. The final step to achieve a theory of timbre that encompasses both the materiality and the signification paradoxes is to make immaterialist materialism operative through the inescapable performativity, the infinite now, of the drastic event.

In 2004, Carolyn Abbate's seminal article 'Music - Drastic or Gnostic?' introduced Jankélévitch's ineffable to a wider musicological readership. Focusing on the immediacy and eventness of musical experience, Abbate called for a musicology that researches the performative and corporeal aspects of playing and listening to music next to the more traditional hermeneutics of musical scores and historical facts. Drastic musicology does not occupy itself with the gnostic facts derived from scores, composer biographies, and historical developments, but with such non-cognitive thoughts as 'doing this really fast is fun' (Abbate, 
Pre-proof manuscript for publication in Contemporary Music Review 36(6), 2017. Do not quote without author's permission.

2004, p. 511). It does not interpret music after the event of musicking, but assesses being in that very event: it focuses only on the infinitely stretched now that Jankélévitch and Lyotard describe. Within that now, drastic musicology assesses what Abbate calls 'musical performance's strangeness,' in which 'earthy' and 'unearthly' qualities, that is its immaterial and material qualities - Lyotard would say its sentiment sonore and the musicking animacoexist (Abbate, 2004, p. 508). Abbate is deeply critical of the mystification of music's ineffability, which often triggers hermeneutic searches for 'truth' in deeply opaque waters, and which she describes aptly as the 'cryptographic sublime' (Abbate, 2004, pp. 524-7). Her article advocates a musicology that is both drastic and gnostic - simply because musical reality needs both kinds of assessment.

Timbre is a supremely drastic quality of music: it has a powerful and immediate agency in which signification and embodiment as well as elusiveness and ephemerality play a role. In her brilliant study of Haydn's orchestral revolution, Emily Dolan contends that timbre is nothing more and nothing less than the human experience of sound: 'it is the concept to which we must turn to describe the immediacies of how sounds strike our ears, how they affect us; (Dolan, 2013, p. 87). Dolan's inadvertently Lyotardian definition of timbre underscores not only the convergence of matter and non-matter in timbre, but also its immediacy, its physicality, its eventness. Timbre is an event that is bound by the temporal and spatial contingencies of musicking, and that can only be understood by combining the gnostic with the drastic, or in terms of the timbral paradox: by combining materialism with idealism.

The timbral sublime, then, is the aporia caused by the accumulation of paradoxes in timbre's event. The timbral noumenon must be considered both a thing and a Thing, an object that is simultaneously not an object. Timbre is not just both an (unstable) object and an (ungraspable) Thing: moreover, it inhabits the abyss between those opposites. The clarity of 
Pre-proof manuscript for publication in Contemporary Music Review 36(6), 2017. Do not quote without author's permission.

Callas's resonance and her remarkable physical control of messa di voce are not the only reasons that her voice takes listeners on an en-chanting flight of magic (cf. Bennett, 2001,. p 6 , p. 34 , p. 153): that corporeality is nothing more and nothing less than the material alpha to a sublime omega. Ecstatic descriptions of her divine voice, on the other hand, fail to recognise the painstakingly physical origins of these impressive vocal performances. The secret of 'La Divina' is the paradox of timbre: the singular encounter of heterogeneous musical agencies leading to unpredictably affective sounds.

The terror and pleasure that this non-approachable but physically knowable no-Thing causes can be traced back at least to the early Romantic era, to which Dolan argues timbre was key because 'ultimately timbre [...] is aesthetic attention itself' (Dolan, 2013, p. 89). The drastic event of timbre lures listeners into the non-time and non-space of musical aesthetics: to turn our ear to timbre is to embrace the im/material arrive-t-il of Lyotardian sound-feeling, the aesthetics of a grainy sublime. Timbre's paradox is its impossible allure. 
Pre-proof manuscript for publication in Contemporary Music Review 36(6), 2017. Do not quote without author's permission.

\section{References}

Abbate, C (2004).“Music - Drastic or Gnostic?” Critical Inquiry 30/3: 505-536.

Anderson, J. (2000), “A provisional history of spectral music”. Contemporary Music Review 19/2: 7-22.

Barthes, R. (1977) “The Grain of the Voice”, 179-189 in Image Music Text: Essays selected and translated by Stephen Heath. London: Fontana Press.

Bennett, Jane (2001) The Enchantment of Modern Life: Attachments, Crossings, and Ethics. Princeton: Princeton University Press.

Berlioz, H. (1844) Grand Traité d'Instrumentation et d'Orchestration Modernes. Translated by Hugh Macdonald (2002). Cambridge: Cambridge University Press.

Blesser, B. and L.-R. Salter (2007). Spaces Speak, Are You Listening? Experiencing Aural Architecture. Cambridge, MA: The MIT Press.

Boulez, P. (1987) “Timbre and Composition - Timbre and Language”. Contemporary Music Review 2: 161-171.

Brillenburgh-Wurth, K. (2009) Musically Sublime: Indeterminacy, Infinity, Irresolvability. New York: Fordham University Press.

Dahlhaus, C. (1989). Nineteenth-Century Music. Translated by J. Bradford Robinson. Berkeley: University of California Press.

Dolan, E. (2013) The Orchestral Revolution: Haydn and the Technologies of Timbre. Cambridge: Cambridge University Press.

Dolar, M. (2006) A Voice and Nothing More. Cambridge, MA: MIT Press.

Eidsheim, N. S. (2015) Sensing Sound: Singing \& Listening as Vibrational Practice. Durham and London: Duke University Press.

Goehr, L. (1998). The Quest for Voice: Music, Politics, and the Limits of Philosophy. Oxford: Oxford University Press. 
Pre-proof manuscript for publication in Contemporary Music Review 36(6), 2017. Do not quote without author's permission.

Hamilton, Andy (2007) Aesthetics \& Music. London: Continuum.

Hoffmann, E.T.A. (1813), “Beethoven's Instrumental Music”, 35-57 in O. Strunk, ed. (1965) Source Readings in Music History: The Romatic Era. New York: Norton.

Jankélévitch, Vladimir ([1983] 2003) Music and the Ineffable. Transl. Carolyn Abbate. Princeton: Princeton University Press.

Leipert, T. (2013) “Destination Unknown: Jean-François Lyotard and Orienting Musical Affect. Contemporary Music Review 31/5-6: 425-438.

Lyotard, J.-F.(1991), The Inhuman. Cambridge: Polity Press.

---. (1997), Postmodern Fables, transl. Georges van den Abbeele. Minneapolis: University of Minnesota Press.

---. (1996) “Music and Postmodernity”. New Formations 66/2 (2009): 37-45.

Middleton, R. (2006) Voicing the Popular: On the Subjects of Popular Music. New York: Routledge.

Nancy, J.-L. (2007). Listening. New York: Fordham University Press.

Paul, J. (1795) “Garden concert by Stamitz”, 24-34 in O. Strunk, ed. (1965) Source Readings in Music History: The Romatic Era. New York: Norton.

Schoenberg, A. (1922) Harmonielehre. II. vermehrte und verbesserte Auflage. Vienna: Universal-Edition.

Steiger, R. (2002) Gnadengegenwart: Johann Sebastian Bach im Kontext lutherischer Orthodoxie und Frömmigkeit. Stuttgart-Bad Canstatt: fromann-holzboog.

Stockhausen, K. (1958) "Electronic and Instrumental Music", 370-380 in C. Cox and D. Warner, eds. (2010), Audio Culture: Readings in Modern Music. New York/London: Continuum.

---. (1964) “Musik im Raum”, Texte zu eigenen Werken und zur Kunst Anderer. Cologne: Verlag M. DuMont Schauberg 
Pre-proof manuscript for publication in Contemporary Music Review 36(6), 2017. Do not quote without author's permission.

Tagg, P. (2013). Music's Meanings: A Modern Musicology for Non-Musos. New York and Huddersfield: The Mass Media Music Scholars’ Press.

Walser, R. (1993) Running with the Devil: Power, Gender, and Madness in Heavy Metal Music. Hanover, NH: University Press of New England.

Watkins, H. and Esse, M (2015) "Down with Disembodiment; or Musicology and the Material Turn," Women and Music 19: 160-168. 
Pre-proof manuscript for publication in Contemporary Music Review 36(6), 2017. Do not quote without author's permission. 